\title{
CHORDS HALVING THE AREA OF A PLANAR CONVEX SET
}

\author{
A. Grüne, R. Klein, C. Miori And S. Segura Gomis
}

\begin{abstract}
Let $K \subset \mathbb{R}^{2}$ be a compact convex set in the plane. A halving chord of $K$ is a line segment $p \hat{p}, p, \hat{p} \in \partial K$, which divides the area of $K$ into two equal parts. For every direction $v$ there exists exactly one halving chord. Its length $h_{A}(v)$ is the corresponding (area) halving distance. In this article we give inequalities relating the minimum and maximum (area) halving distance $h_{A}$ and $H_{A}$ of a convex closed region $K \subset \mathbb{R}^{2}$ to other geometric quantities of $K$, namely the minimal width $\omega$, the diameter $D$, the perimeter $p$, the inradius $r$, the circumradius $R$, and the area $A$. We try to find tight inequalities, and characterize their extremal sets (the sets attaining equality).
\end{abstract}

Mathematics subject classification (2000): 52A40, 52A10.

Key words and phrases: halving chord, halving distance, fencing problems, area bisections, Zindler curves, geometric inequalities, diametral chords.

\section{REFERENCES}

[1] H. AuERBACH, Sur un problème de M. Ulam concernat l'èquilibre des corps flottants, Studia Math. , 7, (1938), 247-250.

[2] A. BIEBERBACH, Über eine Extremaleigenschaft des Kreises, Jber. Deutsch. Math.-Vereinig, 24, (1915), 121-142. Zbl 18, p.175.

[3] T. BONNESEN, W. FenChel, Theory of convex bodies (1934), traslated by L. Boron et al., BCS Assoc., Moscow, ID, (1987), section 42.

[4] A. CERDÁN, Comparing the relative volume with the relative inradius and the relative width, Preprint.

[5] D. ChaKerian, P. R. GOODEY, Inequalities involving convex sets and their chords, Annals of Discrete Mathematics, 20, (1984), 93-101.

[6] A. CIANCHI, On relative isoperimetric inequalities in the plane, Boll. Unione Mat. Italiana, 7, (3-B) (1989), 289-325.

[7] H. T. CROFt, K. J. Falconer AND R. K. GuY, Unsolved problems in Geometry, Springer-Verlag, New York, A26, (1991).

[8] A. Dumitrescu, A. Ebbers-Baumann, A. Grüne, R. Klein and G. Rote, On geometric dilation and halving chords, In Proc. 9th Worksh. Algorithms and Data Structures (WADS 2005), volume 3608 of Lecture Notes Comput. Sci. Springer, August 2005.

[9] A. Dumitrescu, A. Ebbers-Baumann, A. Grüne, R. Klein And G. Rote, On geometric dilation of closed curves, graphs and point sets, preprint, August 2005.

[10] A. DuMITRESCU, A. GRÜNE AND G. ROTE, Improved lower bound on the geometric dilation of point sets, In Abstracts 21st European Workshop Comput. Geom., pp. 37-40. Technische Universiteit Eindhoven, 2005.

[11] A. EbBers-BAUMAn, A. GRÜNE AND R. KleIN, Geometric dilation of closed planar curves: new lower bounds, to appear in special issue of Computational Geometry: Theory and Applications dedicated to Euro-CG '04, 2004.

[12] H. G. EGGLESTON, The maximal length of chords bisecting the area or perimeter length of plane convex sets, Journal London Math. Soc., 36, (1961).

[13] P. R. Goodey, Mean square inequalities for chords of convex sets, Israel Journal of Mathematics, 42, (1982), 132-150.

[14] P. R. GOODEY, Area and perimeter bisectors of planar convex sets, Preprint (2005). 
[15] P. C. HAMmer, T. J. SMith, Conditions equivalent to central symmetry of convex curves, Proc. Cambridge Philos. Soc., 60, (1964), 779-785. MR 30, 506.

[16] T. KuвOTA, Einige Ungleichheitsbeziehungen über Eilinien und Eifä̈chen, Sci. Rep. Tǒhoku Univ., 12, (1923), 45-65.

[17] C. MiORI, C. Peri AND S. Segura Gomis, On fencing problems, Journal of Mathematical Analysis and Applications, 300, (2) (2004), 265-521.

[18] K. RADZISZEWSKI, Sur les cordes qui partagent l'aire d'un ovale en 2 parties égales, Ann. Univ. Mariae Curie-Sklodowska Sect., A 8, (1954), 89-92.

[19] R. SCHNEIDER, Convex bodies: The Brunn-Minkowski theory, Cambridge University Press, 1993.

[20] P. R. ScotT, P. W. AwYONG, Inequalities for convex sets, Journal of Inequalities in Pure and Applied Mathematics, 1, (1) 6 (2000).

[21] K. ZINDLER, Über konvexe Gebilde, Teil. Monatsh. Math. Phys., 31, (1921), 25-56. Jbuch. 48, p. 833. 